\title{
The impact of gasification temperature on the process characteristics of sorption enhanced reforming of biomass
}

\author{
J. Fuchs $^{1}$ (1) • J. C. Schmid ${ }^{1} \cdot$ S. Müller ${ }^{1} \cdot$ A. M. Mauerhofer ${ }^{1}$ • F. Benedikt ${ }^{1} \cdot$ H. Hofbauer $^{1}$
}

Received: 21 March 2019 / Revised: 8 May 2019 / Accepted: 9 May 2019 / Published online: 31 May 2019

(C) The Author(s) 2019

\begin{abstract}
Especially carbon-intensive industries are interested in a decarbonization of their processes. A technology, which can contribute to a significant reduction of the carbon footprint, is the so-called sorption enhanced reforming process. The sorption enhanced reforming process uses a dual fluidized bed reactor system with limestone as a bed material for the thermochemical conversion of biomass into a valuable nitrogen-free product gas. This product gas can be used for further synthesis processes like methanation. The dependency of the product gas composition on the gasification temperature is already a well-known fact. Nevertheless, detailed investigations and models of the effect on elemental balances (especially carbon) of the process are missing in the literature and are presented in this work. Therefore, previously published data from different pilot plants is summarized and is discussed on a mass balance. Based on this information, investigations on the product gas equilibrium composition are presented and conclusions are drawn: it can be shown that the sorption enhanced reforming process can be divided into two sub-processes, namely "carbonation dominated sorption enhanced reforming" and "water-gas shift dominated sorption enhanced reforming." The sub-process carbonation dominated SER is characterized by a high deviation from the water-gas shift equilibrium and a nearly constant $\mathrm{CO}$ content in the product gas over gasification temperature $\left(<700{ }^{\circ} \mathrm{C}\right)$. The sub-process water-gas shift dominated SER can be identified by a steep increase of the CO content in the product gas over temperature and nearly equilibrium state of the water-gas shift reaction $\left(700-760^{\circ} \mathrm{C}\right)$.
\end{abstract}

Keywords Biomass $\cdot$ Hydrogen $\cdot$ Biohydrogen $\cdot$ Carbon sequestration

\begin{tabular}{|c|c|}
\hline \multicolumn{2}{|c|}{ Abbreviations } \\
\hline$\dot{N}_{i, y, \text { in } / \text { out }}$ & $\begin{array}{l}\text { Molar flow of component " } i \text { " }(\mathrm{C}, \mathrm{H} \text { or } \mathrm{O} \text { ) in " } y \text { " } \\
\text { (fuel, } \mathrm{PG} \text {, etc.) as "in" (input) or "out" (output) of } \\
\text { the modeled system [mol/s] }\end{array}$ \\
\hline$\dot{m}_{\text {fuel }}$ & Biomass mass flow $[\mathrm{kg} / \mathrm{s}]$ \\
\hline$K_{P}(T)$ & $\begin{array}{l}\text { Equilibrium constant of a specific chemical reac- } \\
\text { tion (dependent on } \mathrm{T} \text { ) }\end{array}$ \\
\hline$V_{m}$ & Molar volume at $1 \mathrm{~atm}$ and $0{ }^{\circ} \mathrm{C}\left(0.0224 \mathrm{~m}^{3} / \mathrm{mol}\right)$ \\
\hline$Y_{P G}$ & Product gas yield $\left[\mathrm{m}^{3}{ }_{\mathrm{STP}, \mathrm{db}} / \mathrm{kg}_{\text {fuel,daf }}\right]$ \\
\hline$p_{i}$ & Partial pressure of component $i$ \\
\hline$y_{j, y}$ & $\begin{array}{l}\text { Molar fraction " } j "\left(\mathrm{CO}, \mathrm{H}_{2} \text {, etc.) in " } y "\right. \\
\text { (fuel, } \mathrm{PG} \text {, etc.) }\end{array}$ \\
\hline$\nu_{i}$ & Stoichiometric factor of component $i$ \\
\hline $\mathrm{C}$ & Carbon \\
\hline
\end{tabular}

J. Fuchs

josef.fuchs@tuwien.ac.at

1 TU Wien, Institute of Chemical, Environmental and Bioscience Engineering (ICEBE), Getreidemarkt 9/166, 1060 Wien, Austria

$\begin{array}{ll}\text { CR } & \text { Combustion reactor } \\ \text { daf } & \text { Dry and ash free } \\ \mathrm{db} & \text { Dry basis } \\ \mathrm{GR} & \text { Gasification reactor } \\ \text { mass.- } \% & \text { Percent by mass } \\ \mathrm{PG} & \text { Product gas } \\ \mathrm{SER} & \text { Sorption enhanced reforming } \\ \mathrm{T} & \text { Temperature }\left[{ }^{\circ} \mathrm{C}\right] \\ \mathrm{WGS} & \text { Water-gas shift } \\ p \delta_{e q, C a} & \text { Logarithmic equilibrium deviation of the } \\ p \delta_{e q}, & \text { Lystem } \mathrm{CaCO} \mathrm{C}_{3}(\mathrm{~s}) / \mathrm{CaO}(\mathrm{s}) / \mathrm{CO}_{2}(\mathrm{~g}) \\ W G S & \text { water gas shift reaction }\end{array}$

\section{Introduction}

Energy security, air pollution, and climate change - these challenges raise the question of a widely available and storable, environmentally friendly, and carbon-free energy carrier. 
Especially, carbon-intensive industries like steel industry are interested in a decarbonization of their processes. A technology, which could contribute to a significant reduction of the carbon footprint of a steel mill could be the so-called sorption enhanced reforming (SER) process, is a variation of the dual fluidized bed (DFB) steam gasification of biomass [1]. The product of the DFB steam gasification is a nearly nitrogenfree product gas, mainly consisting of hydrogen $\left(\mathrm{H}_{2}\right)$, carbon monoxide $(\mathrm{CO})$, carbon dioxide $\left(\mathrm{CO}_{2}\right)$, and methane $\left(\mathrm{CH}_{4}\right)$. Compared to the conventional DFB steam gasification process with gasification temperatures around $800-850{ }^{\circ} \mathrm{C}[2,3]$, the SER process combines the advantages of both conventional biomass gasification and $\mathrm{H}_{2}$ production [4-6]. Typically, the conventional DFB steam gasification process reaches $\mathrm{H}_{2}$ contents in the product gas up to 45 vol.- $\%_{\mathrm{db}}$, whereas with the SER process, $\mathrm{a}_{2}$ content between 70 and 75 vol.. $\%{ }_{\mathrm{db}}$ can be gained. A steam-blown gasification reactor and an air-blown combustion reactor are the main parts for the process. The combustion reactor provides the necessary heat for the overall endothermic steam gasification via combustion of residual char from gasification. Due to the use of limestone as bed material and suitable temperature levels in both reactors, a decarbonization of the product gas and therefore the generation of a product gas with high $\mathrm{H}_{2}$ contents are possible (Fig. 1). The product gas could be used as a supporting reduction agent in a blast furnace to reduce the fossil carbon share on the one hand [7]. On the other hand, it can be used for the synthesis processes like methanation [8].

It has already been shown that the SER process leads to a product gas with increased reduction potential $[9,10]$, and further investigations were recommended to provide customized operation conditions of the process [9]. Theoretical thermodynamic investigations regarding the bed material renewable rate and bed material cycle rate have been presented in [11], and experimental considerations regarding the impact of bed material cycle rate and its influence on carbon balance have been published in [12]. Also, the description of the product gas composition in dependence of gasification temperature is well known [13]. However, a detailed characterization of the SER process over a vast temperature range is missing in the literature. Especially, the carbon balance over temperature is of great relevance for further use of the product gas.

\section{Materials and methods}

\subsection{Sorption enhanced reforming}

The main function of the bed material, which circulates between the two reactors, is the heat transport from the combustion reactor to the gasification reactor. Additionally, it acts as a transport medium of the residual char from the gasification reactor to the combustion reactor. Further, a suitable bed material is able to capture gaseous components from the product gas: in the SER process, limestone (mainly $\mathrm{CaCO}_{3}$ ) is used as a bed material. In situ $\mathrm{CO}_{2}$ capture in the gasification reactor according to Eq. (1), and its release in the combustion reactor is possible (Eq. (2)) by operating both reactors in a suitable temperature range. This allows the $\mathrm{CO}_{2}$ capture in the gasification reactor and its release in the combustion reactor. The temperature ranges for gasification and combustion reactor during SER depend on the equilibrium partial pressure of $\mathrm{CO}_{2}$ in Eq. (1). Typical temperatures in the gasification reactor are between 600 and $700{ }^{\circ} \mathrm{C}$, whereas in the combustion reactor, the bed material is heated up above $830^{\circ} \mathrm{C}$. Stimulation of the water-gas shift reaction is obtained by the decreased $\mathrm{CO}_{2}$ content in the product gas (Eq. (3)). Therefore, a product gas composition with a $\mathrm{H}_{2}$ content up to 75 vol.- $\%_{\mathrm{db}}$ and $\mathrm{CO}_{2}$ contents of 5 vol.. $\%$ db can be reached.

$$
\begin{array}{ll}
\mathrm{CaO}+\mathrm{CO}_{2} \rightarrow \mathrm{CaCO}_{3} & \Delta H_{R}^{650}=-170 \mathrm{~kJ} / \mathrm{mol} \\
\mathrm{CaCO}_{3} \rightarrow \mathrm{CaO}+\mathrm{CO}_{2} & \Delta H_{R}^{850}=167 \mathrm{~kJ} / \mathrm{mol} \\
\mathrm{CO}+\mathrm{H}_{2} \mathrm{O} \leftrightarrow \mathrm{CO}_{2}+\mathrm{H}_{2} & \Delta H_{R}^{650}=-36 \mathrm{~kJ} / \mathrm{mol}
\end{array}
$$

For many synthesis processes like methanation, a certain $\mathrm{H}_{2}$ to $\mathrm{CO}$ ratio is necessary. Typically, the product gas
Fig. 1 Principle of gasification with $\mathrm{CO}_{2}$ capture (SER)

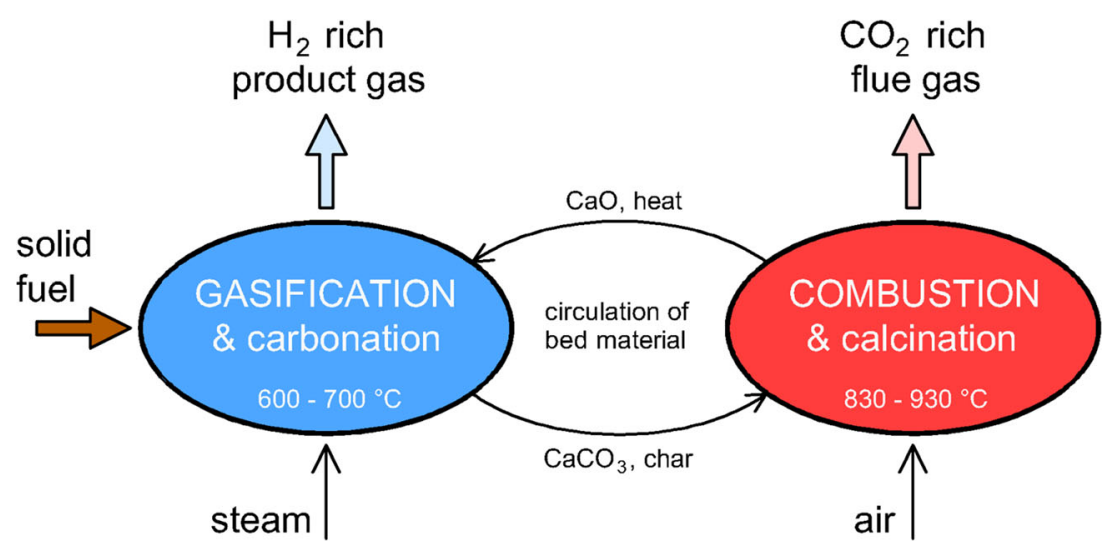


composition of the SER process is highly dependent on gasification temperature and bed material cycle rate $[12,13]$. Via SER, an in situ adjustment of the $\mathrm{H}_{2}$ to $\mathrm{CO}$ ratio between 2 and 9 is possible, which is clearly superior over the conventional gasification with olivine as the bed material, where only a $\mathrm{H}_{2}$ to $\mathrm{CO}$ ratio up to 2 can be adjusted. Figure 2 shows the main product gas components and the $\mathrm{H}_{2}$ to $\mathrm{CO}$ ratio of SER (limestone) and the conventional gasification with olivine as the bed material over temperature.

\subsection{Assumptions for modeling}

The experimental results of different pilot plants are used as the basis for the modeling approach presented in this paper [14-17]. The results include experiments with pilot plants of significant plant sizes up to $200 \mathrm{~kW}_{\text {th }}$. Therefore, the presented values are highly representative and could also be used as a basis for scale-up to plant sizes in MW-scale. Two selected plant designs are presented in Fig. 3: TU Wien has designed an advanced dual fluidized bed test plant for the gasification of various fuels. A sketch of the plant is shown in Fig. 3 (left).

The reactors of the $100 \mathrm{~kW}_{\text {th }}$ test plant are about $5 \mathrm{~m}$ high. The advanced reactor design enhances the gas-solid contact by a column with turbulent fluidized zones (upper gasification reactor), which is placed subsequent to the lower bubbling bed of the gasification reactor. The geometrical modifications in this upper part lead to an improved bed material holdup [18] and enlarge the range of applicable fuels because of higher tar and char conversion rates compared to other DFB systems. Further, gravity separators with gentle separation characteristics instead of cyclones support the use of soft bed materials such as limestone. The separation system prohibits high velocities of gas and particles and minimizes attrition effects. Additionally, a bed material cooling in the upper loop seal enables the defined setting of temperature differences between the gasification and combustion reactor for SER. A staged air input into the combustion reactor allows the effective control of the bed material cycle rate. Additional information can also be found in $[12,13,19,20]$.

A sketch of the $200 \mathrm{~kW}_{\text {th }}$ test plant at IFK Stuttgart is shown in Fig. 3 (right). According to [21, 22], the plant consists of a $6 \mathrm{~m}$ high gasification reactor and a $10 \mathrm{~m}$ high combustion reactor. The control of the bed material cycle rate is done via an L-valve, which allows the recirculation of entrained bed material from the combustion reactor directly to the combustion reactor again. Further information and details about the experimental campaigns can be found in [14, 17].

The main product gas composition in dependence of temperature from different sources [14-17] is summarized in Fig. 4. It can be seen that the results are in a narrow range. This is remarkable, since the experiments were conducted with different plants and at different universities (TU Wien, University Stuttgart) with different process conditions (biomass fuel type, steam to carbon ratio, etc.). Typically, a $\mathrm{H}_{2}$ content about 70 vol.- $\%_{\mathrm{db}}$ can be reached in the temperature range between 600 and $700{ }^{\circ} \mathrm{C}$, whereas the lowest $\mathrm{CO}$ and $\mathrm{CO}_{2}$ contents can be reached in this temperature range as well. With regard to the $\mathrm{CH}_{4}$ content in the product gas, a nearly linear decrease of the content in the dry product gas can be observed with increasing gasification temperature. The trend for higher hydrocarbons $\mathrm{C}_{x} \mathrm{H}_{y}$ including ethene, ethane, and propane is similar, but not that clear. All authors found a nearly linear increase of the product gas yield with increasing temperature. The data summarized from different sources is used as a basis for the development of a mass balance based model of the gasification reactor. The overall objective of the model is to establish a detailed description of the carbon balance of the system and, secondly, to provide investigations and a description of the process regarding chemical equilibria
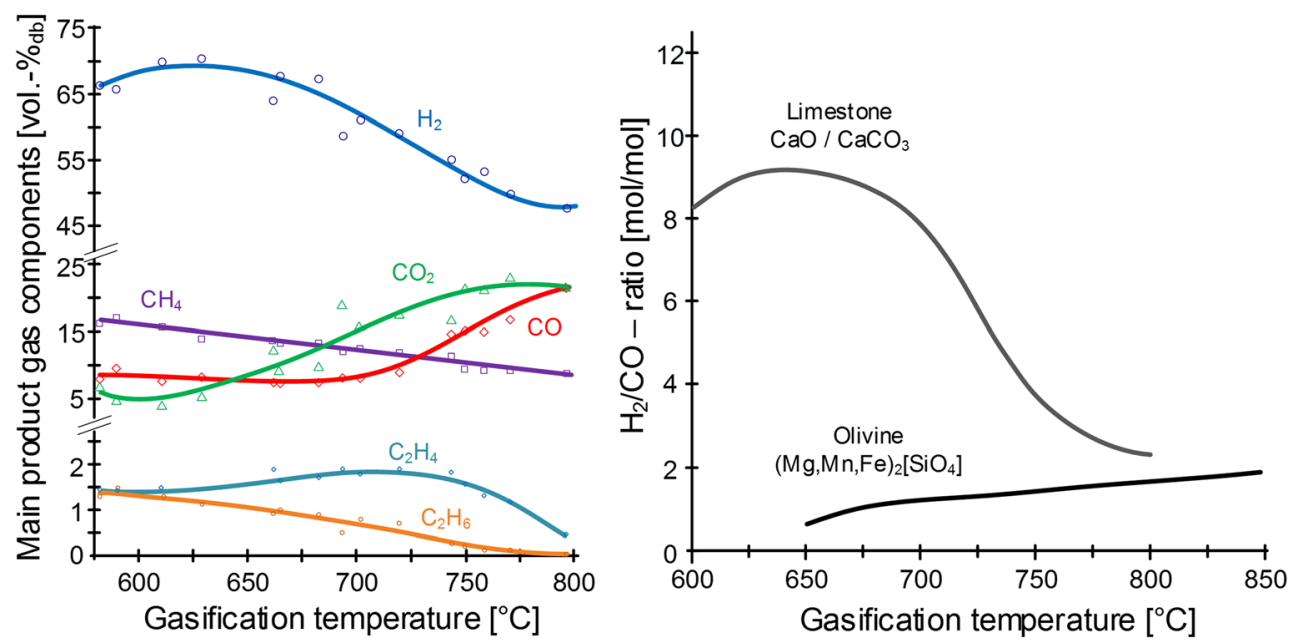

Fig. 2 Main product gas components (left) and $\mathrm{H}_{2}$ to $\mathrm{CO}$ ratio of the SER process (right) over temperature $\left(\mathrm{N}_{2}\right.$-free basis and extended with internal data from the advanced $100 \mathrm{~kW}_{\text {th }}$ test plant at TU Wien from $[4,13]$ ) 

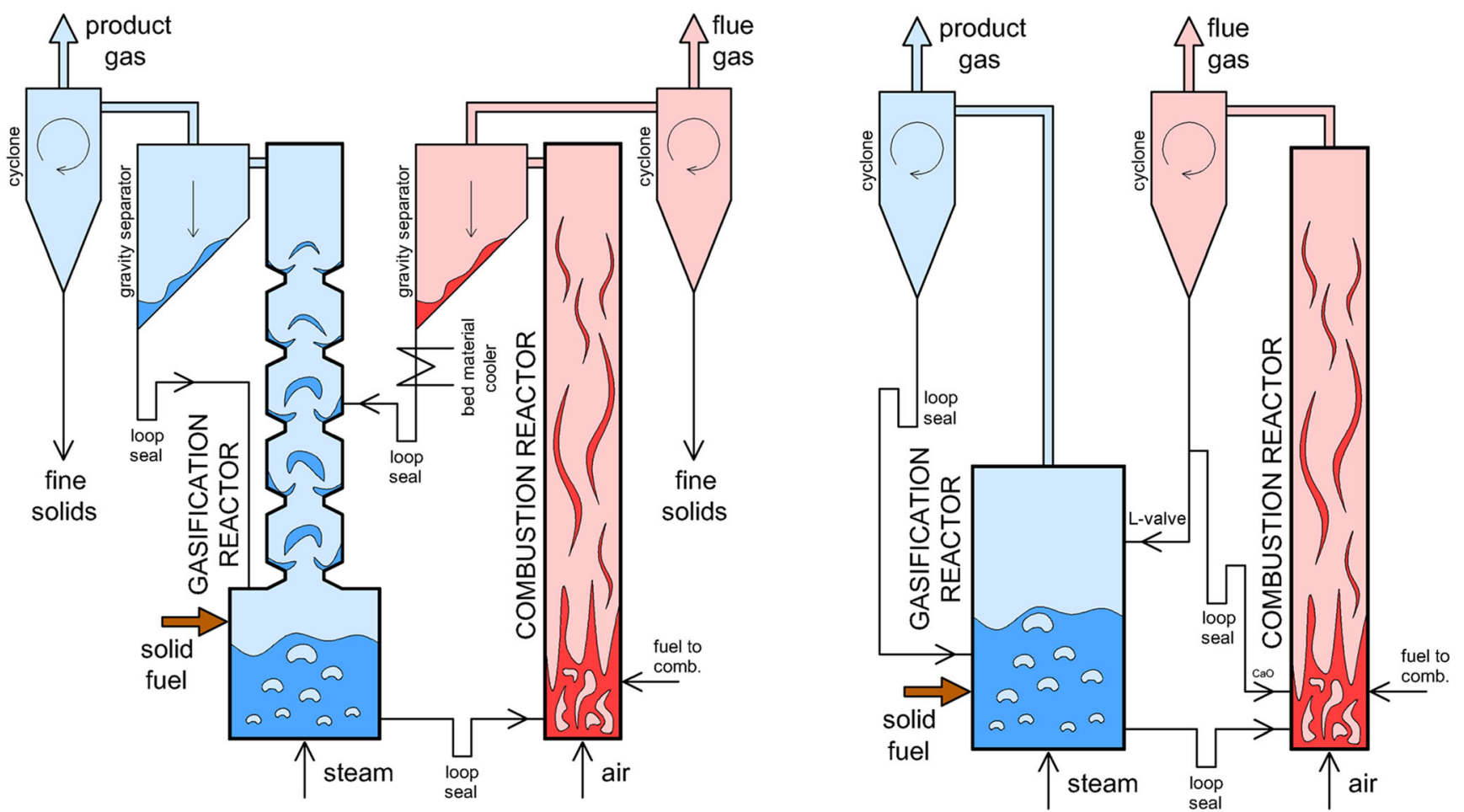

Fig. 3 Advanced $100 \mathrm{kWth}$ test plant at TU Wien (left) and $200 \mathrm{kWth}$ test plant at IFK Stuttgart (right)

to further increase the understanding of the SER process. The data used for modeling is plotted in black dotted lines in Fig. 4. A significant deviation from the measured data can be observed for the assumptions of $\mathrm{C}_{x} \mathrm{H}_{y}$ No higher hydrocarbons than $\mathrm{C}_{2} \mathrm{H}_{4}$ are considered in the model. Therefore, in the model, $\mathrm{C}_{2} \mathrm{H}_{4}$ is used as a component, which compensates for all higher hydrocarbons and also tar. Thus, a significantly higher amount of $\mathrm{C}_{2} \mathrm{H}_{4}$ is used to take all the residual carbon containing components into account.

To calculate a full quantitative balance of the components carbon $(\mathrm{C})$, hydrogen $(\mathrm{H})$, and oxygen $(\mathrm{O})$, information about the introduced fuel is necessary. Table 1 shows the fuel composition of different types of fuel and therefore shows that biogenic fuels (especially lignocellulosic fuels) usually have a similar fuel composition regarding the $\mathrm{C}, \mathrm{H}$, and $\mathrm{O}$ content. In addition, the amount of volatiles is in a narrow range for biogenic fuels (volatiles typically indicate if the amount of residual char from gasification is similar). Therefore, it can be assumed that the applied model is valid for a broad range of biogenic fuels and not only for softwood. Table 1 also shows that the results must not be used for other fuel types like lignite or plastics: the ratio between the elements $\mathrm{C}, \mathrm{H}$, and $\mathrm{O}$ and the volatiles are too different. $\mathrm{C}_{1} \mathrm{H}_{1.5} \mathrm{O}_{0.7}$ was used as a general simple formula representing biomass for modeling of the process. This is based on the formulas published in [23], where a molar $\mathrm{H}$ to $\mathrm{C}$ ratio from 1.35 to 1.5 and a molar $\mathrm{O}$ to $\mathrm{C}$ ratio from 0.62 to 0.7 for wood are stated.
Last but not least, the amount of introduced steam must be known. For all calculations, a steam to fuel ratio based on dry biomass of $0.8 \mathrm{~kg}_{\text {steam }} / \mathrm{kg}_{\text {biomass }}$ is used. This is a typical value used in the SER experiments of the $100 \mathrm{~kW}_{\text {th }}$ test plant at TU Wien [13].

\subsection{Modeling}

Based on the assumptions presented in Fig. 4 and Table 1, a model was invented to calculate the full quantitative balance of the main components $\mathrm{C}, \mathrm{H}$, and $\mathrm{O}$ for the gasification reactor over a temperature range from 600 to $850^{\circ} \mathrm{C}$ (including char and $\mathrm{CO}_{2}$ bound in $\mathrm{CaCO}_{3}$, which leaves the gasification reactor). The model is based on the assumption that all the components introduced into the gasification reactor (fuel $\dot{N}_{i, \text { fuel,in }}$ and steam $\dot{N}_{i, \text { H2O in }}$ ) must either leave the reactor as (i) product gas $\dot{N}_{i, \mathrm{PG}, \text { out }}$ and (ii) steam $\dot{N}_{i, \mathrm{H} 2 \mathrm{O}, \text { out }}$ or remain as solid residuals and are subsequently transported to the combustion reactor (Eq. 4). The two possible solid types are (iii) char $\dot{N}_{i, \text { char,out }}$ and (iv) $\mathrm{CO}_{2}$ in the bed material (as $\mathrm{CaCO}_{3}$ ) $\dot{N}_{i, \mathrm{CO}_{2} \text { in } \mathrm{CaCO}_{3} \text {,out }}$. A simplified scheme can be found in Fig. 5. Further, pictures of bed material samples taken from the lower loop seal (after gasification reactor) and the upper loop seal (after combustion reactor) during a test run with the advanced $100 \mathrm{~kW}_{\text {th }}$ test plant at TU Wien are displayed in Fig. 5. It is obvious that for the applied conditions, approximately the whole char is burned in the combustion reactor: 
Fig. 4 Main product gas composition from different sources [14-17] and assumptions used for modeling
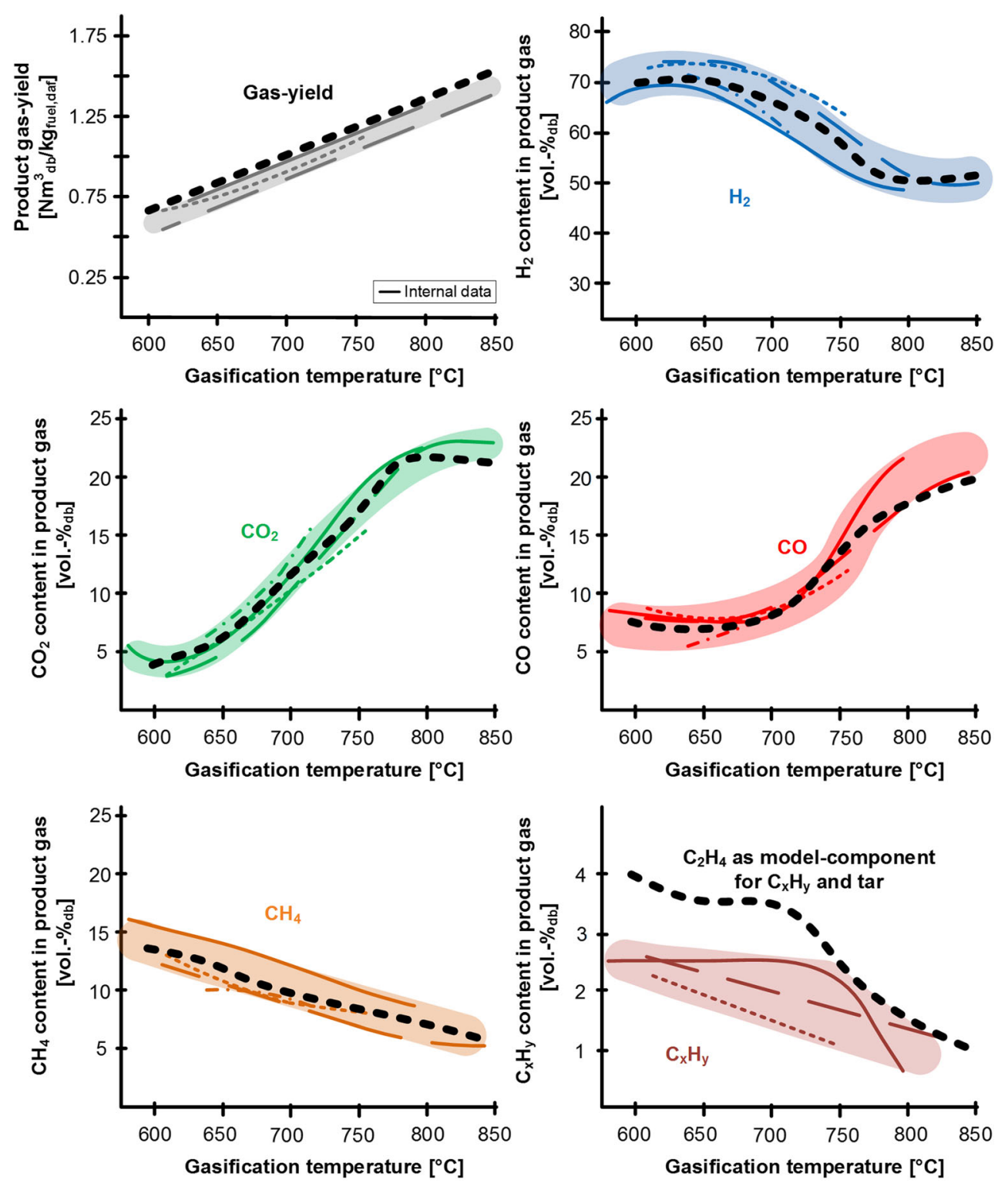

Armbrust et al. 2014 [14], $200 \mathrm{kWth}$ DFB pilot plant gasifier, IFK Stuttgart Soukup 2009 [15], Classical 100 kWth DFB gasifier, TU Wien

- Schmid et al. 2017 [16], Advanced 100 kWth DFB gasifier, TU Wien

- - Poboß 2016 [17], different facilities (averaged), IFK Stuttgart

-.- Assumptions used for modelling in this work nearly no more black char particles are visible on the upper loop seal sample (bed material cycle rate of $7.7 \mathrm{~h}^{-1}$, GR temperature of $650^{\circ} \mathrm{C}$, and maximum $\mathrm{CR}$ temperature of $880^{\circ} \mathrm{C}$ ).

$$
\begin{aligned}
\dot{N}_{i, \text { fuel, in }} & +\dot{N}_{i, \mathrm{H} 2 \mathrm{O}, \text { in }}=\dot{N}_{i, \mathrm{PG}, \text { out }}+\dot{N}_{i, \mathrm{H} 2 \mathrm{O}, \text { out }} \\
& +\dot{N}_{i, \text { char, out }}+\dot{N}_{i, \mathrm{CO} 2 \text { inCaCO}, \text { out }} \quad i=\mathrm{C}, \mathrm{H}, \mathrm{O} \\
\dot{N}_{C, \mathrm{PG}, \text { out }} & =Y_{\mathrm{PG}} \times \dot{m}_{\text {fuel }} / V_{m} \\
& \times\left(y_{\mathrm{CO}, \mathrm{PG}}+y_{\mathrm{CO} 2, \mathrm{PG}}+y_{\mathrm{CH} 4, \mathrm{PG}}+2 \times y_{\mathrm{C} 2 \mathrm{H} 4, \mathrm{PG}}\right)
\end{aligned}
$$


Table 1 Typical fuel compositions of different fuel types and composition used for modeling

\begin{tabular}{|c|c|c|c|c|c|c|c|}
\hline & & Soft wood & Rice husks & Hazelnut shells & Exh. olive pomace & lignite & $\begin{array}{l}\text { poly- } \\
\text { propylene }\end{array}$ \\
\hline Volatiles & mass.- $\%_{\text {daf }}$ & 86 & 81 & 76 & 80 & 54 & \\
\hline Carbon (C) & mass. $-\%_{\text {daf }}$ & 50.8 & 51.2 & 52.8 & 52.4 & 68.4 & 85.7 \\
\hline Hydrogen $(\mathrm{H})$ & mass. $-\%_{\text {daf }}$ & 5.9 & 6.1 & 5.6 & 6.2 & 3.9 & 14.3 \\
\hline Oxygen $(\mathrm{O})$ & mass.- $\%_{\text {daf }}$ & 43.1 & 42 & 41.2 & 40.1 & 26.3 & \\
\hline Nitrogen $(\mathrm{N})$ & mass.- $\%_{\text {daf }}$ & 0.2 & 0.55 & 0.4 & 1.1 & 0.88 & \\
\hline Sulfur (S) & mass.- $\%_{\text {daf }}$ & 0.005 & 0.07 & 0.027 & 0.11 & 0.4 & \\
\hline Chlorine $(\mathrm{Cl})$ & mass.- $\%_{\text {daf }}$ & 0.005 & 0.11 & 0.028 & 0.15 & 0.052 & \\
\hline $\mathrm{C}_{1} \mathrm{H}_{x} \mathrm{O}_{y}$ & & $\mathrm{C}_{1} \mathrm{H}_{1.39} \mathrm{O}_{0.64}$ & $\mathrm{C}_{1} \mathrm{H}_{1.43} \mathrm{O}_{0.62}$ & $\mathrm{C}_{1} \mathrm{H}_{1.28} \mathrm{O}_{0.59}$ & $\mathrm{C}_{1} \mathrm{H}_{1.42} \mathrm{O}_{0.57}$ & $\mathrm{C}_{1} \mathrm{H}_{0.68} \mathrm{O}_{0.29}$ & $\mathrm{C}_{1} \mathrm{H}_{2}$ \\
\hline $\mathrm{C}_{1} \mathrm{H}_{x} \mathrm{O}_{y}$ model & & $\mathrm{C}_{1} \mathrm{H}_{1.5} \mathrm{O}_{0.7}$ & & & & model not valid & \\
\hline
\end{tabular}

Equations 5, 6, and 7 show the equations for each component $(\mathrm{C}, \mathrm{H}, \mathrm{O})$ in the product gas according to stoichiometric considerations. The molar flow of $\mathrm{H}$ and $\mathrm{O}$ in the gaseous water from gasification $\left(\dot{N}_{i, \mathrm{H} 2 \mathrm{O}, \text { out }}\right)$ can be calculated by the assumption that all the $\mathrm{H}$, which is not in the dry product gas must be in the gaseous steam (Eq. 8). This is only valid if the char is modeled as pure $\mathrm{C}$ and therefore does not contain any $\mathrm{H}$ or O. Further, Eq. 9 demonstrates the calculation of the molar flow of $\mathrm{O}$ via bed material $\left(\mathrm{CO}_{2}\right.$ transport in $\left.\mathrm{CaCO}_{3}\right)$ : all the remaining $\mathrm{O}$, which is not leaving the system via the product gas or the gaseous water, contributes to the molar flow of $\mathrm{O}$ in the bed material. Finally, the molar flow of $\mathrm{C}$ in the char can be calculated by subtracting the $\mathrm{C}$ flow in the product gas and the $\mathrm{C}$ flow in the bed material (Eq. 9). As already mentioned in Eqs. 8, 9, and 10, the char composition is modeled as pure $\mathrm{C}$. In fact, char also contains $\mathrm{H}$ and $\mathrm{O}$. A model for pyrolysis of biomass and the composition of the remaining char over temperature has been proposed by Neves et al. [24]. For this work, it is assumed that the model for pyrolysis is approximately valid for biomass steam gasification as well. This fact has already been verified in a previous work [25], and the used equations are presented in Eqs. 11, 12, 13, and 14. The results for Eqs.
Fig. 5 Simplified scheme of the flows of the quantitative balance within the gasification reactor

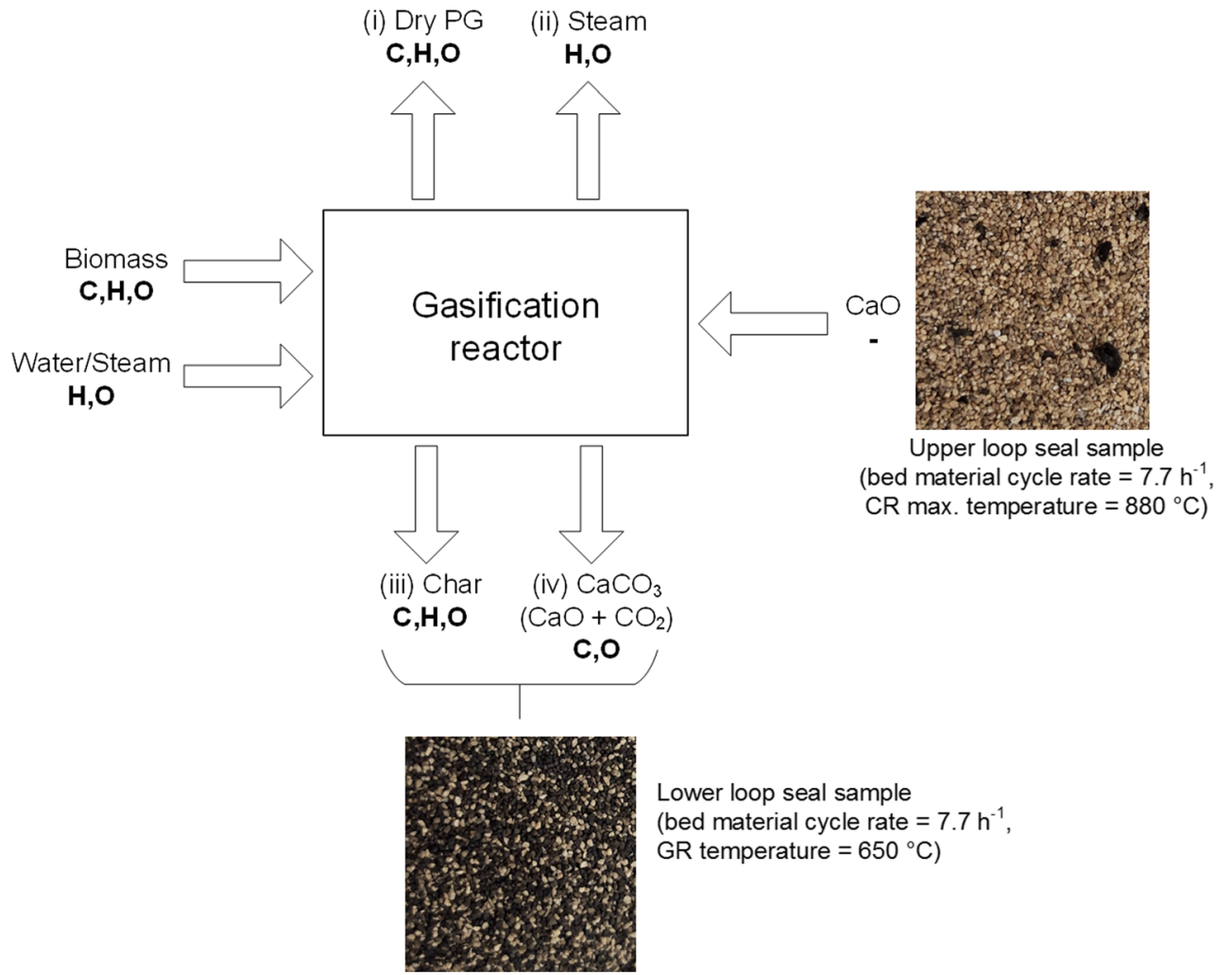


12 to 14 are displayed in Fig. 6: the carbon content in the char typically rises with temperature:

$$
\begin{aligned}
y_{\text {total, char }}= & \frac{0.93-0.92 \times \exp \left(-0.42 \times 10^{-2} \times T\right)}{12} \\
+ & \frac{0.07-0.85 \times \exp \left(-0.48 \times 10^{-2} * T\right)}{16} \\
+ & \frac{-0.41 \times 10^{-2}+0.10 \times \exp \left(-0.24 \times 10^{-2} \times T\right)}{1} \\
y_{\mathrm{C}, \text { char }}= & \left(0.93-0.92 \times \exp \left(-0.42 \times 10^{-2} \times T\right)\right) \\
& / 12 / y_{\text {total,char }} \\
y_{\mathrm{O}, \text { char }}= & \left(0.07-0.85 \times \exp \left(-0.48 \times 10^{-2} \times T\right)\right) \\
& / 16 / y_{\text {total }, \text { char }} \\
y_{\mathrm{H}, \text { char }}= & \left(-0.41 \times 10^{-2}+0.10 \times \exp \left(-0.24 \times 10^{-2} \times T\right)\right) \\
& / 1 / y_{\text {total, char }}
\end{aligned}
$$

The integration of Eqs. 11, 12, 13, and 14 into the model (Eqs. 4, 5, 6, 7, 8, 9, and 10) leads to the modification of Eqs. 8,9 , and 10 to Eqs. 15,16 , and 17. The set of equations is now nonlinear and is solved by iteration.

$$
\begin{gathered}
\dot{N}_{H, \mathrm{H} 2 \mathrm{O}, \text { out }}=\dot{N}_{H, \text { fuel, in }}+\dot{N}_{H, \mathrm{H} 2 \mathrm{O}, \mathrm{in}}-\dot{N}_{H, \mathrm{PG}, \text { out }} \\
-\dot{N}_{C, \text { char, out }} / y_{C, \text { char }} \times y_{H, \text { char }} \\
\dot{N}_{O, \mathrm{CO} 2 \text { inCaCO3, out }}=\dot{N}_{O, \text { fuel,in }}+\dot{N}_{O, \mathrm{H} 2 \mathrm{O}, \text { in }}-\dot{N}_{O, \mathrm{PG}, \text { out }} \\
-\dot{N}_{O, \mathrm{H} 2 \mathrm{O}, \text { out }}-\dot{N}_{C, \text { char, out }} / y_{C, \text { char }} \times y_{O, \text { char }} \\
\dot{N}_{C, \text { char,out }}=\dot{N}_{C, \text { fuel, in }}-\dot{N}_{C, \mathrm{PG}, \text { out }}-\dot{N}_{C, \mathrm{CO} 2 \text { inCaCO3,out }}
\end{gathered}
$$

Further investigations focus on the calculation of chemical equilibria as well as their deviation from equilibrium state [26]. The general formula for calculation of the deviation from equilibrium $p \delta_{\mathrm{eq}}$ is given in Eq. 18. One can derive from Eq. 18 that a value of zero for $p \delta_{\text {eq }}$ means that the equilibrium state

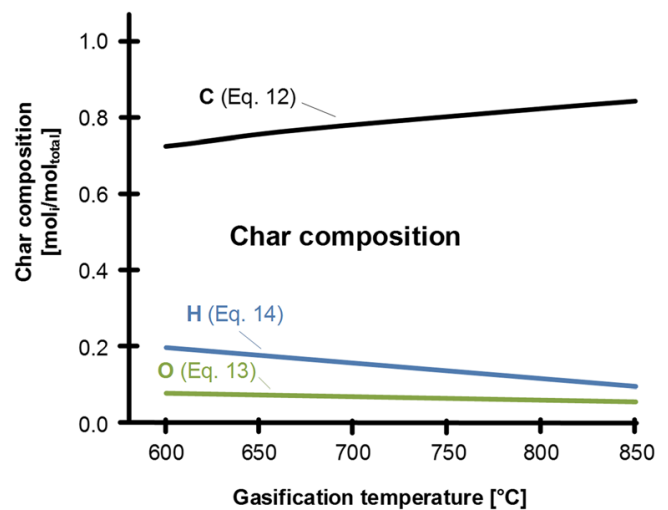

Fig. 6 Molar $\mathrm{C}, \mathrm{H}$, and $\mathrm{O}$ content in biomass char in dependence of temperature based on [24] is reached, whereas a deviation from zero indicates a deviation from the equilibrium state. A change of the algebraic sign shows a change in the reaction direction.

$p \delta_{\mathrm{eq}}\left(p_{i}, T\right)=\log _{10}\left[\frac{\prod_{i} p_{i}^{\nu_{i}}}{K_{P}(T)}\right]$

\section{Results and discussion}

\subsection{Solid carbon balance}

The solution of the set of equations Equations 4-10 and Equations 15-17 regarding to the carbon transport to the combustion reactor is shown in Fig. 7: at $600{ }^{\circ} \mathrm{C}$, nearly $50 \%$ of the $\mathrm{C}$ in the fuel is transported to the combustion reactor via char. Further, about $30 \%$ are sorbed by the bed material as $\mathrm{CO}_{2}$ and therefore are also transported to the combustion reactor. At $800{ }^{\circ} \mathrm{C}$, only $30 \%$ of the $\mathrm{C}$ remains in the char, and practically no $\mathrm{C}$ is removed via the bed material as $\mathrm{CaCO}_{3}$. This makes sense, since from a thermodynamic point of view, the SER process can take place up to $760^{\circ} \mathrm{C}$ [13]. The model applied in this work shows $\mathrm{CO}_{2}$ transport via bed material also for higher temperatures than $760^{\circ} \mathrm{C}$. This is dedicated to the fact, that the temperature distribution in the gasification reactor is not uniform in most cases. It is most likely that for an indicated gasification temperature of, e.g., $800{ }^{\circ} \mathrm{C}$, colder spots exist, where $\mathrm{CO}_{2}$ sorption may be possible. Last but not least, it can be seen that between 60 and $80 \%$ of the total $\mathrm{C}$ from the fuel can be transported to the combustion reactor at temperatures between 700 and $600{ }^{\circ} \mathrm{C}$. It should be noticed that the char transport to the combustion reactor influences the energy balance of the total system. Therefore, an adaptation of the bed material cycle rate and/or cooling in the upper loop seal is necessary to maintain the correct temperature levels of the reactors.

Figure 7 also shows the difference between the calculation of char as pure $\mathrm{C}$ and as a mixture of $\mathrm{C}, \mathrm{H}$, and $\mathrm{O}$ according to Neves et al. [24]: the total amount of carbon, which leaves the gasification reactor, is not changed. This can be explained by the fact that all carbon which does not leave the gasification reactor in a gaseous form must leave the gasification reactor as solid to the combustion reactor. Since the change of the char composition does not change any set parameters of the product gas composition in Fig. 4, the total carbon to the combustion reactor must remain the same. However, the distribution of the carbon between char and $\mathrm{CO}_{2}$ in $\mathrm{CaCO}_{3}$ is changed slightly. Less char is formed, but more $\mathrm{CO}_{2}$ is absorbed by considering $\mathrm{C}, \mathrm{H}$, and $\mathrm{O}$ in the char. All further calculations in 


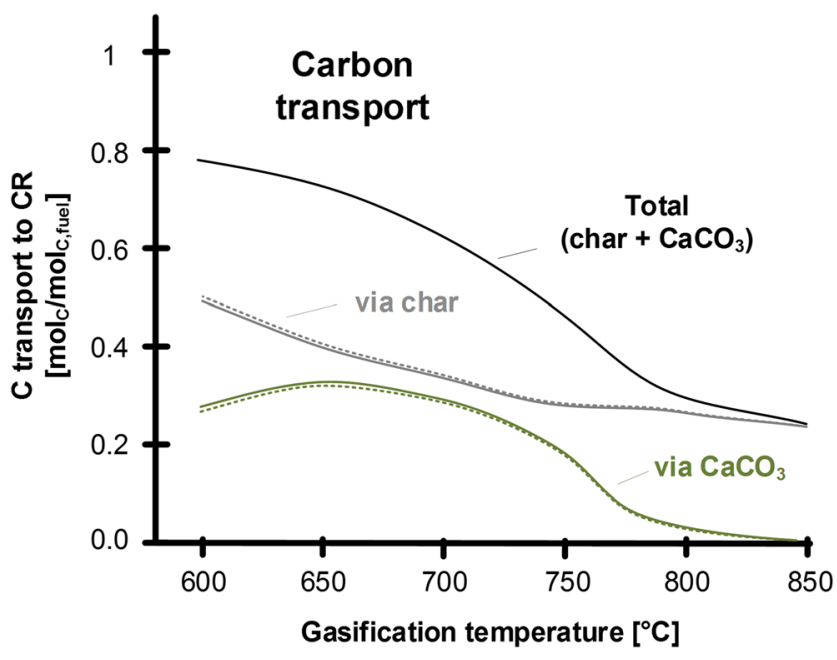

....... Carbon balance calculated with char as pure $\mathrm{C}$

- Carbon balance calculated with char composition according to Figure 6

Fig. 7 Carbon transport to the combustion reactor

this work were done with the char composition proposed by Neves et al. [24].

\subsection{Product gas equilibrium calculation}

Based on the findings of the quantitative balance the amount of elements leaving the gasification reactor as a solid (via char and as $\mathrm{CO}_{2}$ in $\mathrm{CaCO}_{3}$ ) and vice versa the amount of elements, which are present as a gas, are known now. The Gibbs free energy minimization method is applied to the remaining gaseous components in the gasification reactor to find the theoretical equilibrium composition of the product gas. The equilibrium calculation was conducted with the software HSC [27].

By considering the formation of $\mathrm{H}_{2}, \mathrm{CO}, \mathrm{CO}_{2}, \mathrm{CH}_{4}$, and $\mathrm{H}_{2} \mathrm{O}$ as possible components for equilibrium calculation, the equilibrium results displayed in Fig. 8 are gained. Additionally, Fig. 8 contains the range of the product gas components from the experimental results of the pilot plants. One can see that especially the trends for the $\mathrm{H}_{2}$ content and the $\mathrm{CO}$ content in the product gas are similar: the $\mathrm{H}_{2}$ content decreases with increasing temperature, whereas the $\mathrm{CO}$ content is increasing with temperature. However, a strong deviation of the theoretical equilibrium composition and the experimentally collected data can be found for the other components. Especially, the water content and the $\mathrm{CH}_{4}$ content in the product gas differ highly. The $\mathrm{CH}_{4}$ content in the product gas should obviously be on a very low level according to thermodynamic equilibrium calculations. This fact has already been found by other authors and is well known [28, 29]. Schuster et al. [29] states that the devolatilization of biomass produces a high amount of $\mathrm{CH}_{4}$ and higher hydrocarbons. These components typically do not react to the equilibrium concentrations of $\mathrm{CO}, \mathrm{CO}_{2}$, and $\mathrm{H}_{2}$ under the conditions in the SER process.

Therefore, as a second approach, the amount of $\mathrm{C}$ and $\mathrm{H}$ from $\mathrm{CH}_{4}$ and $\mathrm{C}_{x} \mathrm{H}_{\mathrm{y}}$, which is produced during the first devolatilization phase of fresh biomass particles, is eliminated for the homogeneous gas-gas equilibrium calculations. It turns out that an average of $10 \%$ of the carbon in the fuel is bound as gaseous $\mathrm{CH}_{4}$ (Fig. 9). This value remains nearly constant over the whole temperature range. However, this is an additional proof for the theory that a constant amount of nearly inert $\mathrm{CH}_{4}$ is released during devolatilization. Consequently, the components, which remain for the equilibrium calculation, are $\mathrm{H}_{2}$, $\mathrm{H}_{2} \mathrm{O}, \mathrm{CO}$, and $\mathrm{CO}_{2}$. These components are all part of the water-gas shift reaction (Eq. 3), which can now be identified as governing gas-gas equilibrium reaction. Again, in Fig. 9, the results of the equilibrium calculations are displayed and are compared to the range of experimental results. Now, a very good agreement can be observed, especially for temperatures above $700{ }^{\circ} \mathrm{C}$. For temperatures below $700{ }^{\circ} \mathrm{C}$, a slightly higher $\mathrm{CO}_{2}$ content and a slightly lower $\mathrm{CO}$ content are predicted by the equilibrium model compared to the experimental results. Nevertheless, the trend for all components is predicted correctly now by the equilibrium model.

To investigate the SER process in more detail based on the previous findings, the logarithmic equilibrium deviation $p \delta_{\mathrm{eq}}$, WGS for the water-gas shift reaction (Eq. 3) and the logarithmic equilibrium deviation $p \delta_{\text {eq, } \mathrm{Ca}}$ for the system $\mathrm{CaCO}_{3} / \mathrm{CaO} /$ $\mathrm{CO}_{2}$ (Eq. 1 and 2 of the experimentally determined product gas composition (Fig. 4) is calculated and shown in Fig. 10.

Regarding $p \delta_{\mathrm{eq}}$, wGS for the water-gas shift reaction, it can be seen in Fig. 10 that the experimental results are far away from the equilibrium composition at $600{ }^{\circ} \mathrm{C}$. However, there is a steep incline until $700{ }^{\circ} \mathrm{C}$ approximately, where $p \delta_{\text {eq, wGS }}$ is already close to zero (Fig. 10, black dot number I). From there on, the incline of $p \delta_{\text {eq, WGS }}$ is small and remains close to zero. $p \delta_{\text {eq, Ca }}$ declines constantly and reaches zero at about $760{ }^{\circ} \mathrm{C}$ (Fig. 10, black dot number II). From this point on, thermodynamically, no more $\mathrm{CO}_{2}$ sorption of the bed material is possible. These characteristic temperatures can also be found in the product gas composition. Therefore, Fig. 10 shows the experimental data for $\mathrm{CO}$ and $\mathrm{CO}_{2}$ from the $100 \mathrm{~kW}_{\text {th }}$ test plant at TU Wien $[7,16]$ as well. From 600 to $700{ }^{\circ} \mathrm{C}$, a more or less constant content of $\mathrm{CO}$ can be observed, but from $700{ }^{\circ} \mathrm{C}$ on (Fig. 10, black dot number 1), a steep increase of the $\mathrm{CO}$ content is visible. Considering the $\mathrm{CO}_{2}$ content in the product gas shows that the $\mathrm{CO}_{2}$ content is mainly increasing from $600{ }^{\circ} \mathrm{C}$ on until $760{ }^{\circ} \mathrm{C}$ is reached (Fig. 10, black dot number 2). Close to this point, where the $\mathrm{CO}_{2}$ sorption via the bed material stops, the highest $\mathrm{CO}_{2}$ content in the product gas can be observed.

Concluding the findings of Fig. 10 shows that the SER process can be divided into two sub-processes. The first one 
Fig. 8 Equilibrium product gas composition over temperature, basis for calculations (framed): $\mathrm{C}$, $\mathrm{H}$, and $\mathrm{O}$ from (I) char and (II) in $\mathrm{CaCO}_{3}$ transported $\mathrm{CO}_{2}$ are eliminated for gas-gas equilibrium calculation
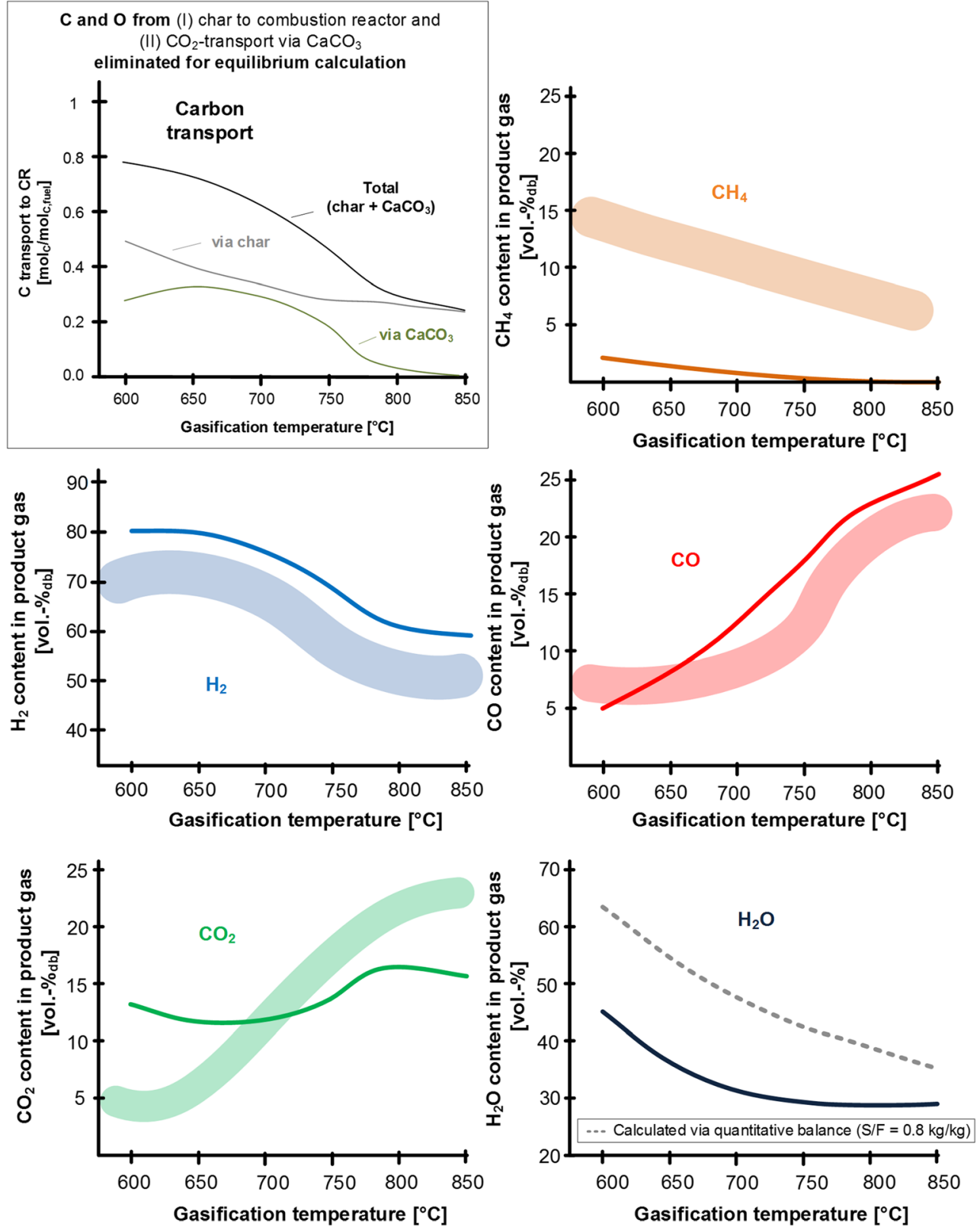

Equilibrium composition, Fuel: Biomass $\left(\mathrm{C}_{1} \mathrm{H}_{1.5} \mathrm{O}_{0.7}\right), \mathrm{S} / \mathrm{F}=0.8 \mathrm{~kg} / \mathrm{kg}$ Range of results from DFB experiments (Figure 4)

between 600 and $700{ }^{\circ} \mathrm{C}$ is named "carbonation dominated SER" in Fig. 10. It is mainly characterized by a high equilibrium deviation of the water-gas shift reaction $p \delta_{\mathrm{eq}}$, wGS and a constantly low $\mathrm{CO}$ content in the product gas. Further, the carbonation dominated SER process shows the highest transport rates of $\mathrm{CO}_{2}$ via bed material (see also Fig. 7). Thus, the product gas composition is influenced significantly by the water-gas shift reaction, because removal of $\mathrm{CO}_{2}$ from the product gas leads to enhanced consumption of $\mathrm{CO}$ and $\mathrm{H}_{2} \mathrm{O}$ for the production of high $\mathrm{H}_{2}$ contents. However, due to the dominating influence of the $\mathrm{CO}_{2}$ removal (carbonation) of the bed material, the water-gas shift reaction does not reach an equilibrium state.

The second sub-process is called "water-gas shift dominated SER," which points out that between 700 and $760^{\circ} \mathrm{C}$, the water-gas shift equilibrium of the product gas is almost reached. This can be traced back to the enhanced gas-gas kinetics because of higher temperatures on the one hand and the decreasing influence of the carbonation reaction on the other hand. Thus, from $700{ }^{\circ} \mathrm{C}$ on, also the $\mathrm{CO}$ content starts rising. 
Fig. 9 Equilibrium product gas composition over temperature, basis for calculations (framed): $\mathrm{C}$, $\mathrm{H}$, and $\mathrm{O}$ from (I) char, (II) in $\mathrm{CaCO}_{3}$ transported $\mathrm{CO}_{2}$, and (III) $\mathrm{CH}_{4}+\mathrm{C}_{x} \mathrm{H}_{y}$ are eliminated for gasgas equilibrium calculation
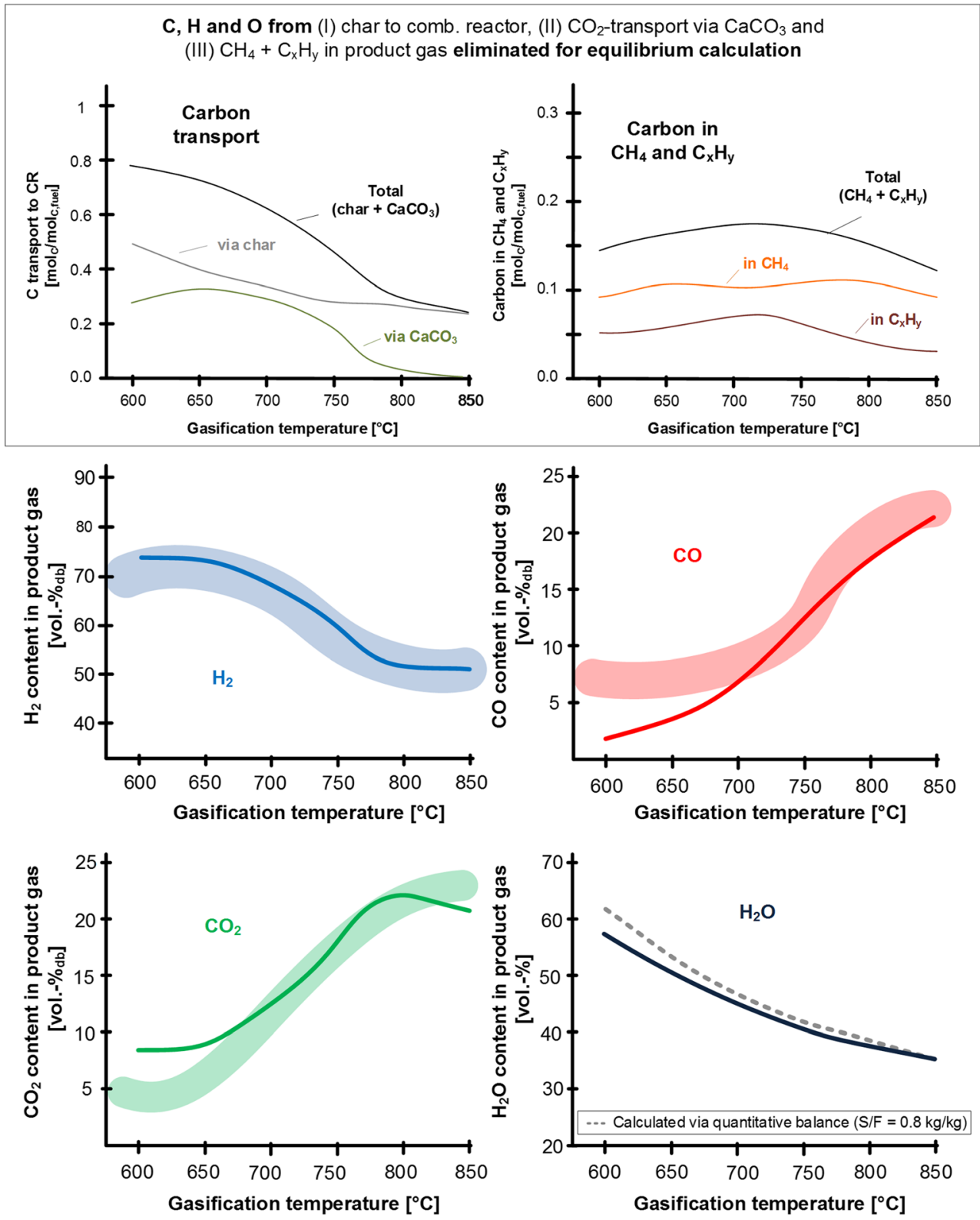

Equilibrium composition, Fuel: Biomass $\left(\mathrm{C}_{1} \mathrm{H}_{1.5} \mathrm{O}_{0.7}\right), \mathrm{S} / \mathrm{F}=0.8 \mathrm{~kg} / \mathrm{kg}$ Range of results from DFB experiments (Figure 4)

At about $760{ }^{\circ} \mathrm{C}$, the $\mathrm{CO}_{2}$ sorption of the bed material stops due to the thermodynamics of the system $\mathrm{CaCO}_{3} / \mathrm{CaO} / \mathrm{CO}_{2}$. From this point on, the process is conventional, which means gasification without $\mathrm{CO}_{2}$ transport.

\section{Conclusion}

Simple mathematical modeling combined with (product gas) equilibrium calculations provides a deep insight into the SER process. For the temperature range 600 to $800{ }^{\circ} \mathrm{C}$, it has been found that between 50 and $30 \%$ of the $\mathrm{C}$ contained in the fuel is transported from the gasification reactor to the combustion reactor as char. In total (including $\mathrm{C}$ in char and in bed material), about $80 \%$ of the $\mathrm{C}$ in the fuel can be removed from the gasification reactor at low temperatures $\left(\sim 600{ }^{\circ} \mathrm{C}\right)$. By combining these findings with homogeneous gas-gas equilibrium calculations based on the general formula $\mathrm{C}_{1} \mathrm{H}_{1.5} \mathrm{O}_{0.7}$ representing biomass, it turns out that $\mathrm{CH}_{4}$ should be on a very low basis. However, due to the slow kinetics of the $\mathrm{CH}_{4}$ reforming, a significantly higher amount of $\mathrm{CH}_{4}$ can be found in the product gas. Therefore, by considering $\mathrm{CH}_{4}$ as a 


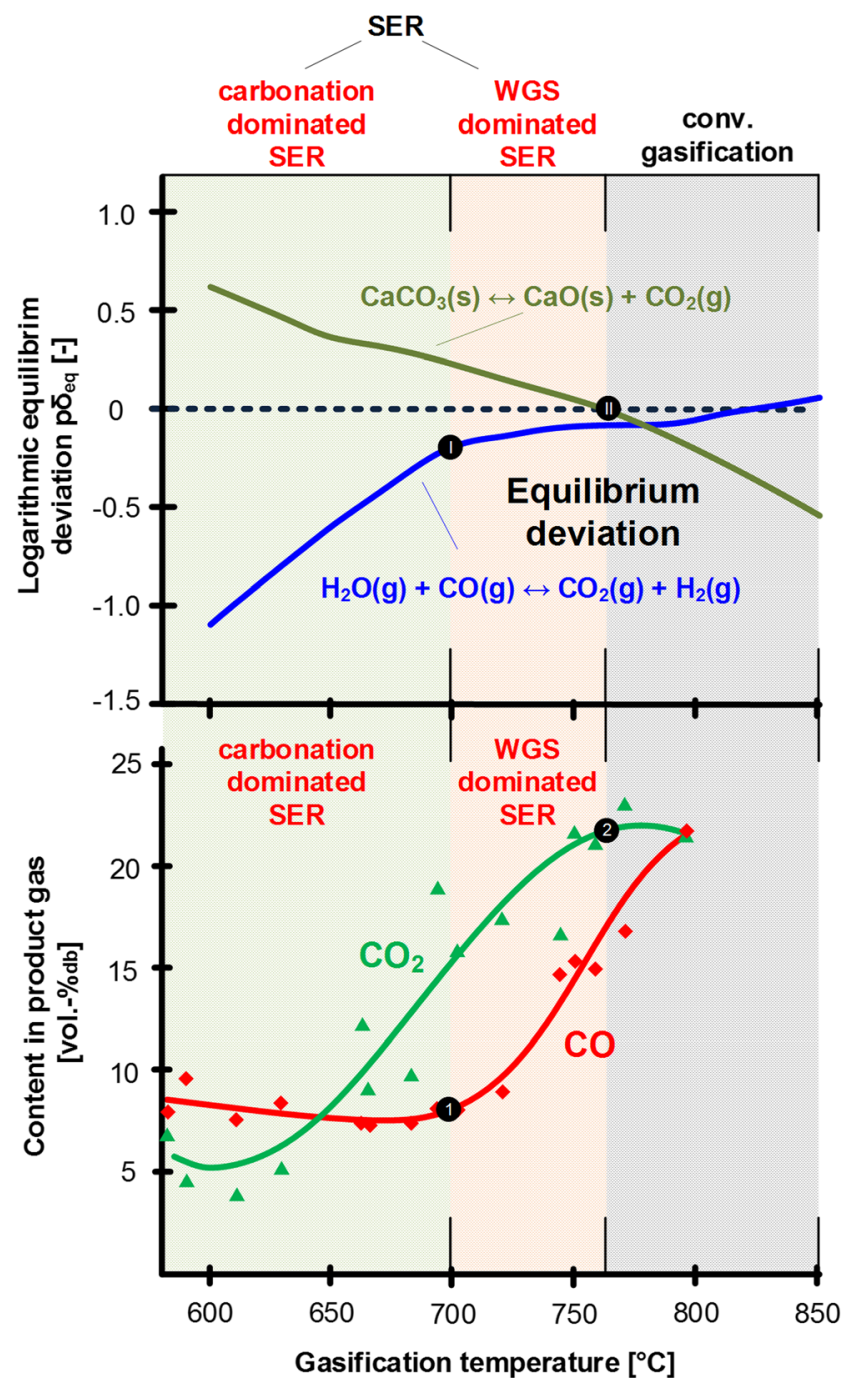

Fig. 10 Characterization of sorption enhanced reforming reforming by equilibrium deviation and product gas composition

constant component in the product gas and using the remaining main components $\mathrm{H}_{2}, \mathrm{CO}, \mathrm{CO}_{2}$, and $\mathrm{H}_{2} \mathrm{O}$ as reactants for gas-gas equilibrium calculations, a satisfactory agreement with experimental results can be found. A detailed analysis of the equilibrium deviation of the watergas shift reaction and the calcination reaction of $\mathrm{CaCO}_{3}$ shows that the SER process can be divided into the two sub-processes: (i) carbonation dominated SER and (ii) water-gas shift dominated SER. The sub-process carbonation dominated SER is characterized by a high deviation from the water-gas shift equilibrium and a constantly low $\mathrm{CO}$ content in the product gas over gasification temperature $\left(<700{ }^{\circ} \mathrm{C}\right)$. The sub-process water-gas shift dominated SER can be identified by a steep increase of the $\mathrm{CO}$ content in the product gas over temperature and nearly equilibrium state of the water-gas shift reaction $\left(700-760^{\circ} \mathrm{C}\right.$ ). Above $760^{\circ} \mathrm{C}$, conventional gasification without $\mathrm{CO}_{2}$ transport can be found.
Acknowledgements The present work is part of the research project RenewableSteelGases in cooperation with voestalpine Stahl $\mathrm{GmbH}$; voestalpine Stahl Donawitz GmbH; K1-MET GmbH; MU Leoben, Lehrstuhl für Verfahrenstechnik des industriellen Umweltschutzes; and JKU Linz, Energieinstitut. RenewableSteelGases receives financial support from the research program "Energieforschung" funded by the "Austrian Climate and Energy Fund."

Funding Information Open access funding provided by TU Wien (TUW).

Open Access This article is distributed under the terms of the Creative Commons Attribution 4.0 International License (http:// creativecommons.org/licenses/by/4.0/), which permits unrestricted use, distribution, and reproduction in any medium, provided you give appropriate credit to the original author(s) and the source, provide a link to the Creative Commons license, and indicate if changes were made.

\section{References}

1. Hofbauer H, Rauch R, Bosch K, Koch R, Aichernig C (2003) Biomass CHP Plant Güssing - A Success Story. In: Bridgewater A.V. (ed.), CPL Press, Liberty House, New Greenham Park, Newsbury, Berks RG19 3UP, UK, 2003, S. 527-536

2. Schmid JC, Wolfesberger U, Koppatz S, Pfeifer C, Hofbauer H (2012) Variation of feedstock in a dual fluidized bed steam gasifier-influence on product gas, tar content, and composition. Environ Prog Sustain Energy 31:205-215. https://doi.org/10. 1002/ep.11607

3. Benedikt F, Fuchs J, Schmid JC, Müller S, Hofbauer H (2017) Advanced dual fluidized bed steam gasification of wood and lignite with calcite as bed material. Korean J Chem Eng 34:1-11. https:// doi.org/10.1007/s11814-017-0141-y

4. Fuchs J, Schmid JC, Müller S, Hofbauer H (2019) Dual fluidized bed gasification of biomass with selective carbon dioxide removal and limestone as bed material: a review. Renew Sust Energ Rev 107:212-231. https://doi.org/10.1016/j.rser.2019.03.013

5. Florin NH, Harris AT (2008) Enhanced hydrogen production from biomass with in situ carbon dioxide capture using calcium oxide sorbents. Chem Eng Sci 63:287-316. https://doi.org/10.1016/j.ces. 2007.09.011

6. Udomsirichakorn J, Salam PA (2014) Review of hydrogenenriched gas production from steam gasification of biomass: the prospect of CaO-based chemical looping gasification. Renew Sust Energ Rev 30:565-579. https://doi.org/10.1016/j.rser.2013.10.013

7. Fuchs J, Schmid JC, Müller S, et al (2017) Erba II Endbericht, Optimierung von „Sorption Enhanced Reforming“ zur Verbesserung der $\mathrm{CO}_{2}$-Bilanz in der Roheisenerzeugung mittels Biomasse

8. Biegger P, Kirchbacher F, Roza Medved A et al (2018) Development of honeycomb methanation catalyst and its application in power to gas systems. Energies 11:1-17. https://doi.org/10. 3390/en11071679

9. Müller S, Koppatz S, Fuchs M, Pröll T, Hofbauer H (2013) Hydrogen Production Based on Conventional Dual Fluid Gasification versus Sorption Enhanced Reforming. In: Proceedings of the International Conference on Polygeneration Strategies (ICPS13), 3-5 Sept. 2013, Vienna, Austria

10. Müller S (2013) Hydrogen from biomass for industry - industrial application of hydrogen production based on dual fluid gasification. TU Wien, $\mathrm{PhD}$ Thesis 
11. Müller S, Pröll T, Hofbauer H (2012) A thermodynamic investigation of dual fluidized bed biomass gasification with sorption enhanced reforming. Proceedings of the 21 st International Conference on Fluidized Bed Combustion (FBC), Naples

12. Fuchs J, Schmid JC, Benedikt F, Müller S, Hofbauer H, Stocker H, Kieberger N, Bürgler T (2018) The impact of bed material cycle rate on in-situ $\mathrm{CO}_{2}$ removal for sorption enhanced reforming of different fuel types. Energy 162:35-44. https://doi.org/10.1016/j. energy.2018.07.199

13. Müller S, Fuchs J, Schmid JC, Benedikt F, Hofbauer H (2017) Experimental development of sorption enhanced reforming by the use of an advanced gasification test plant. Int J Hydrog Energy 42: 29694-29707. https://doi.org/10.1016/j.ijhydene.2017.10.119

14. Armbrust N, Schweitzer D, Gredinger A, et al (2014) Gasification of biomass with in-situ $\mathrm{CO}_{2}$ capture and separation in a $200 \mathrm{~kW}_{\text {th }}$ pilot plant fluidized bed. In: Gasification technologies 2014. Washington D.C., http://www.gasification-syngas.org/uploads/ eventLibrary/12.3 Updated University of Stuttgart Heiko Dieter.pdf. Accessed 052019

15. Soukup G (2009) Der AER - Prozess, Weiterentwicklung in einer Technikumsanlage und Demonstration an einer Großanlage. TU Wien, $\mathrm{PhD}$ Thesis

16. Schmid JC, Fuchs J, Benedikt F et al (2017) Sorption enhanced reforming with the novel dual fluidized bed test plant at TU Wien. In: European Biomass Conference and Exhibition (EUBCE), Stockholm, pp 421-428

17. Poboß N (2016) Experimentelle Untersuchung der sorptionsunterstützten Reformierung. Universität Stuttgart, $\mathrm{PhD}$ Thesis

18. Schmid J, Pröll T, Kitzler H et al (2012) Cold flow model investigations of the countercurrent flow of a dual circulating fluidized bed gasifier. Biomass Convers Biorefinery 2:229-244. https://doi.org/ 10.1007/s13399-012-0035-5

19. Benedikt F, Schmid JC, Fuchs J, Mauerhofer AM, Müller S, Hofbauer H (2018) Fuel flexible gasification with an advanced $100 \mathrm{~kW}$ dual fluidized bed steam gasification pilot plant. Energy 164:329-343. https://doi.org/10.1016/j.energy.2018.08.146

20. Fuchs J, Schmid JC, Benedikt F (2018) A general method for the determination of the entrainment in fluidized beds. Int J Multiphys 12:359-372
21. Hawthorne C, Poboss N, Dieter H, Gredinger A, Zieba M, Scheffknecht G (2012) Operation and results of a $200-\mathrm{kW}_{\text {th }}$ dual fluidized bed pilot plant gasifier with adsorption-enhanced reforming. Biomass Convers Biorefinery 2:217-227. https://doi. org/10.1007/s13399-012-0053-3

22. Schweitzer D, Beirow M, Gredinger A, Armbrust N, Waizmann G, Dieter H, Scheffknecht G (2016) Pilot-scale demonstration of oxySER steam gasification: production of syngas with pre-combustion $\mathrm{CO}_{2}$ capture. Energy Procedia 86:56-68. https://doi.org/10.1016/j. egypro.2016.01.007

23. Kaltschmitt M, Hartmann H, Hofbauer H (2016) Energie aus Biomasse - Grundlagen, Techniken und Verfahren, 3rd ed. Springer-Verlag Berlin Heidelberg. https://doi.org/10.1007/978-3540-85095-3

24. Neves D, Thunman H, Matos A, Tarelho L, Gómez-Barea A (2011) Characterization and prediction of biomass pyrolysis products. Prog Energy Combust Sci 37:611-630. https://doi.org/10.1016/j.pecs. 2011.01.001

25. Brellochs J (2014) Experimentelle Untersuchung und ProzessSimulation der AER-Biomassevergasung zur Erzeugung eines regenerativen Erdgassubstitutes. Universität Stuttgart, $\mathrm{PhD}$ Thesis

26. Pröll T, Hofbauer H (2008) Development and application of a simulation tool for biomass gasification based processes. Int $\mathrm{J}$ Chem React Eng 6:Article A89. https://doi.org/10.2202/1542-6580.1769

27. HSC version 6.12 (n.d) (c) Outotec Research Oy

28. Koppatz S, Pfeifer C, Hofbauer H (2011) Comparison of the performance behaviour of silica sand and olivine in a dual fluidised bed reactor system for steam gasification of biomass at pilot plant scale. Chem Eng J 175:468-483. https://doi.org/10.1016/j.cej.2011.09. 071

29. Schuster G, Löffler G, Weigl K, Hofbauer H (2001) Biomass steam gasification - an extensive parametric modeling study. Bioresour Technol 77:71-79. https://doi.org/10.1016/S0960-8524(00)00115-2

Publisher's note Springer Nature remains neutral with regard to jurisdictional claims in published maps and institutional affiliations. 